\title{
Influence of Thyroid Function on Different Kidney Function Tests
}

\author{
Martin Kimmel Niko Braun Mark Dominik Alscher \\ Division of General Internal Medicine and Nephrology, Department of Internal Medicine, Robert Bosch Hospital, \\ Stuttgart, Germany
}

\section{Key Words}

Chronic Kidney Disease Epidemiology Collaboration equation - Creatinine $\cdot$ Creatinine clearance $\cdot$ Cystatin C . Neutrophil gelatinase-associated lipocalin $\cdot$ Thyroid dysfunction

\begin{abstract}
Background/Aims: The commonly used kidney function tests have limitations, especially in thyroid dysfunction. Therefore, we studied the most commonly used kidney function tests in patients with hypo- and hyperthyroidism and after reaching euthyroidism. Methods: Prospective case series in 16 patients with thyroid dysfunction. Serum creatinine, 24-hour creatinine clearance, calculated glomerular filtration rate (GFR) by Cockroft-Gault, estimated GFR (eGFR) by the Chronic Kidney Disease Epidemiology Collaboration equation, serum cystatin C, eGFR based on cystatin C, eGFR based on a combined (cystatin $C$ and creatinine) formula and plasma neutrophil gelatinase-associated lipocalin (NGAL) were measured in hypo- and hyperthyroidism and after gaining euthyroidism. Results: When free thyroxine $\left(\mathrm{fT}_{4}\right)$ normalized in hypothyroid patients, creatinine decreased and creatinine-based eGFR increased significantly. In contrast, cystatin $C$ increased and eGFR based on cystatin $C$ decreased significantly. There was no significant change in NGAL levels. When $\mathrm{fT}_{4}$ normalized in patients with hyperthyroidism, cre-
\end{abstract}

atinine increased and creatinine-based eGFR decreased significantly. In contrast, cystatin C decreased and cystatin-Cbased GFR increased significantly. There was no significant change in NGAL levels. Conclusions: Thyroid function has a major influence on the vast majority of kidney function tests. Cystatin $C$ is strongly influenced by the thyroid function and should be avoided in thyroid disorders. There was no effect on the plasma NGAL levels. The recommended kidney function test is a measurement of creatinine-based eGFR.

Copyright $\odot 2011$ S. Karger AG, Basel

\section{Introduction}

There is a well-known interaction between thyroid and kidney functions. Thyroid hormones are involved in the growth, development and the physiology of the kidney [1]. Thyroid dysfunction is known to cause significant changes in kidney function: hypo- and hyperthyroidism affect glomerular filtration rate (GFR), renal blood flow, tubular function, water and electrolyte balance and kidney structure [2]. There is a broad discussion on the best kidney function test in different populations [3]. In the absence of known chronic kidney disease, the most commonly used kidney function tests in everyday clinical practice are the two biomarkers serum creatinine and serum cystatin C. The next step in testing is estimat-

Dr. Martin Kimmel

Robert Bosch Hospital

Auerbachstrasse 110

DE-70376 Stuttgart (Germany)

Tel. +49 7118101 3496, E-Mail martin.kimmel@rbk.de 
Table 1a. Clinical characteristics and laboratory results (serum or plasma) in patients before and after therapy of hypothyroidism

\begin{tabular}{|c|c|c|c|c|c|}
\hline \multirow[t]{2}{*}{ Parameter } & \multirow[t]{2}{*}{ Normal } & \multicolumn{2}{|l|}{ Hypothyroidism } & \multicolumn{2}{|c|}{ Normal thyroid function } \\
\hline & & mean $\pm \mathrm{SD}$ & range & mean $\pm S D$ & range \\
\hline \multicolumn{6}{|l|}{ Study population } \\
\hline 3 females, 6 males & & & & & \\
\hline $42 \pm 14(22-65)$ & & & & & \\
\hline \multicolumn{6}{|l|}{ Clinical characteristics } \\
\hline BMI & & $28.0 \pm 4.7$ & $21.5-27.0$ & $27.4 \pm 4.1$ & $22.3-34.9$ \\
\hline Weight, kg & & $87.1 \pm 15.0$ & $65.0-104.0$ & $85.0 \pm 13.5$ & $67.5-104.5$ \\
\hline \multicolumn{6}{|l|}{ Laboratory results } \\
\hline $\mathrm{TSH}, \mathrm{mU} / \mathrm{l}$ & $0.47-4.7$ & $39.50 \pm 26.20^{* *}$ & $11.1-100.5$ & $0.24 \pm 0.46$ & $0.01-1.46$ \\
\hline $\mathrm{T}_{3}, \mathrm{pmol} / \mathrm{l}$ & $0.7-2.3$ & $0.16 \pm 0.32^{* * *}$ & $0-1$ & $1.69 \pm 0.3$ & $1.0-2.2$ \\
\hline $\mathrm{fT}_{4}, \mathrm{pmol} / \mathrm{l}$ & $11.7-28.0$ & $4.8 \pm 0.3^{* * *}$ & $4.5-5.1$ & $24.1 \pm 5.3$ & $13.7-33$ \\
\hline Urea, mg/dl & $20-50$ & $26.4 \pm 6.50$ & $19-39$ & $28.3 \pm 7.3$ & $16-37$ \\
\hline Creatinine, $\mathrm{mg} / \mathrm{dl}$ & $0.5-1.4$ & $1.2 \pm 0.20^{* * *}$ & $0.9-1.4$ & $0.9 \pm 0.1$ & $0.8-1.1$ \\
\hline Creatinine clearance over $24 \mathrm{~h}$ collected, $\mathrm{ml} / \mathrm{min}$ & $80-120$ & $86 \pm 23^{* *}$ & $44-118$ & $115 \pm 36$ & $63-179$ \\
\hline Creatinine clearance (Cockroft-Gault), ml/min & $80-120$ & $92 \pm 14^{* * *}$ & $78-115$ & $117 \pm 16$ & $97-149$ \\
\hline eGFR by CKD-EPI (creatinine based), ml/min & $80-120$ & $68 \pm 12^{* * *}$ & $52-95$ & $93 \pm 15$ & $70-121$ \\
\hline Cystatin C, mg/l & $0.53-0.95$ & $0.80 \pm 0.09^{*}$ & $0.68-0.93$ & $0.88 \pm 0.09$ & $0.77-1.04$ \\
\hline eGFR based on cystatin $\mathrm{C}, \mathrm{ml} / \mathrm{min}$ & $80-120$ & $103 \pm 15^{*}$ & $82-125$ & $90 \pm 11$ & $74.0-106.0$ \\
\hline eGFR based on creatinine and cystatin $\mathrm{C}, \mathrm{ml} / \mathrm{min}$ & $80-120$ & $81 \pm 10^{*}$ & $66-97$ & $90 \pm 11$ & $71-106$ \\
\hline NGAL, ng/ml & $<50$ & $39 \pm 27$ & $30-112$ & $38 \pm 16$ & $30-68$ \\
\hline
\end{tabular}

All parameters measured in serum or plasma samples. Age is given as median \pm standard deviation, with range in parentheses, all other results as means \pm standard deviation. $\mathrm{BMI}=$ Body mass index; TSH $=$ thyroid-stimulating hormone. ${ }^{*} \mathrm{p}<0.05,{ }^{* *} \mathrm{p}<0.003$, *** $\mathrm{p}<0.0001$.

ing the GFR by collected and calculated clearances [creatinine clearance measured in a 24 -hour collection, calculated GFR by Cockroft-Gault or the Chronic Kidney Disease Epidemiology Collaboration (CKD-EPI) equation, estimated GFR (eGFR) based on cystatin C and eGFR based on both (creatinine and cystatin C)]. In case of chronic kidney disease (GFR $<60 \mathrm{ml} / \mathrm{min}$ ), the eGFR rate by formulas, like the MDRD (Modification of Diet in Renal Disease), is the most common, best-validated approach [4]. In case of acute kidney injury the best-validated biomarkers are cystatin $\mathrm{C}$ and neutrophil gelatinaseassociated lipocalin (NGAL) [5, 6]. All kidney function tests have their well-known limitations, and different effects have been described in thyroid dysfunction: in case of the well-established serum creatinine an increase in hypothyreotic state and a decrease in hyperthyroidism have been shown [7], whereas serum cystatin $C$ has been shown to decrease in hypothyroidism and to increase in hyperthyroidism [8-10]. Recently, the newer proposed acute kidney injury marker NGAL has been shown to be a survival factor for thyroid neoplastic cells [11].
None of the previous studies have included several kidney function tests in a single patient cohort. The aim of this study is to compare 8 different kidney function tests [serum creatinine, 24-hour creatinine clearance, calculated creatinine clearance by Cockroft-Gault, calculated GFR by the CKD-EPI equation, serum cystatin C, calculated GFR based on cystatin C, calculated GFR based on both (cystatin C and creatinine) and NGAL] in parallel in a case series of patients with hypo- and hyperthyreosis before and after treatment.

\section{Methods}

\section{Patients}

Hypothyroidism. Nine patients who were under replacement therapy with L-triiodothyronine $\left(\mathrm{L}-\mathrm{T}_{3}\right.$, Thybon $\left.{ }^{\circledR}\right)$ because of total strumectomy for thyroid cancer were recruited for the study. All patients underwent complete medical examination including laboratory tests and vital signs. Two to 6 (median 4 ) weeks before radioiodine therapy $\mathrm{L}-\mathrm{T}_{3}$ replacement was stopped, and the diagnosis of hypothyroidism was confirmed by appropriate clinical and biochemical criteria: thyroid-stimulating hormone 
Table 1b. Clinical characteristics and laboratory results (serum or plasma) in patients before and after therapy of hyperthyroidism

\begin{tabular}{|c|c|c|c|c|}
\hline \multirow[t]{2}{*}{ Parameter } & \multirow[t]{2}{*}{ Normal } & \multicolumn{2}{|c|}{ Hyperthyroidism } & Normal thyroid function \\
\hline & & mean $\pm \mathrm{SD}$ & range & mean $\pm \mathrm{SD}$ \\
\hline
\end{tabular}

Study population

$\begin{array}{ll}\text { Gender } & 6 \text { females, } 1 \text { male } \\ \text { Age, years } & 46 \pm 11(34-57)\end{array}$

\section{Clinical characteristics}

BMI
Weight, kg

6 females, 1 male

Weight, kg

$23.77 \pm 4.63$
$69.54 \pm 7.84$

$20.6-34.0$

$24.49 \pm 4.37$

$21.2-34.2$

Laboratory results

$\mathrm{TSH}, \mathrm{mU} / \mathrm{l}$

$\mathrm{T}_{3}, \mathrm{pmol} / \mathrm{l}$

$\mathrm{fT}_{4}, \mathrm{pmol} / \mathrm{l}$

Urea, $\mathrm{mg} / \mathrm{dl}$

Creatinine, $\mathrm{mg} / \mathrm{dl}$

Creatinine clearance over $24 \mathrm{~h}$ collected, $\mathrm{ml} / \mathrm{min}$

Creatinine clearance (Cockroft-Gault), $\mathrm{ml} / \mathrm{min}$

eGFR by CKD-EPI (creatinine based), $\mathrm{ml} / \mathrm{min}$

Cystatin C, mg/l

eGFR based on cystatin $\mathrm{C}, \mathrm{ml} / \mathrm{min}$

eGFR based on creatinine and cystatin $\mathrm{C}, \mathrm{ml} / \mathrm{min}$

NGAL, ng/ml

$$
\begin{array}{r}
0.47-4.7 \\
0.7-2.3
\end{array}
$$$$
<0.00 \pm 0.0 \quad<0.00-0.02
$$$$
2.5-9
$$

$71.69 \pm 7.57$

$59.0-84.3$

All parameters measured in serum or plasma samples. Age is given as median \pm standard deviation with range in parentheses, all other results as means \pm standard deviation. $\mathrm{BMI}=$ Body mass index; TSH $=$ thyroid-stimulating hormone. ${ }^{*} \mathrm{p}<0.05,{ }^{* *} \mathrm{p}<0.003$, ${ }^{* * *} \mathrm{p}<0.0001$.

above normal (0.47-4.7 mU/l), $\mathrm{T}_{3}$ equal to or below normal $(0.7-$ $2.3 \mathrm{pmol} / \mathrm{l})$, thyroxine $\left(\mathrm{T}_{4}\right)$ below normal $(11.7-28.0 \mathrm{pmol} / \mathrm{l}$; table 1a).

After radioiodine therapy and when patients had received replacement treatment with levothyroxine (Euthyrox ${ }^{\circledR}$, Merck, Darmstadt, Germany; 150-250 $\mu \mathrm{g} /$ day), they were studied again after $13.7 \pm 10.7$ weeks. Normal thyroid function was confirmed by appropriate laboratory tests (table 1a).

Hyperthyroidism. Seven patients suffering from hyperthyroidism (3 Graves' disease, 4 toxic adenomas) were included in the study. Diagnosis was confirmed by appropriate clinical and biochemical tests. Three patients got drug therapy with carbimazole, 4 got a radioiodine therapy (table $1 \mathrm{~b}$ ). The patients were studied again after normalization of thyroid function after $15.7 \pm 6.7$ weeks.

The local ethics committee and regulating government authorities approved the study. Written informed consent was obtained from all patients.

\section{Kidney Function Tests}

In all patients (all Caucasian), the kidney function was measured at each of the 2 time points: in thyroid dysfunction (hypoor hyperthyroidism) and after therapy in euthyroidism by the following 8 methods:
(1) serum levels of creatinine were measured enzymatically;

(2) 24-hour creatinine clearance was calculated after 24-hour urine collection;

(3) calculated creatinine clearance according to the formula of Cockroft and Gault [12];

(4) GFR was estimated based on creatinine by the CKD-EPI equation (no black patients) [13];

females with serum creatinine $\leq 0.7 \mathrm{mg} / \mathrm{dl}$ : eGFR $=144 \times$ (serum creatinine/0.7 $)^{-0.329} \times(0.993)^{\text {age }}$;

females with serum creatinine $>0.7 \mathrm{mg} / \mathrm{dl}$ : eGFR $=144 \times(\mathrm{se}-$ rum creatinine $/ 0.7)^{-1.209} \times(0.993)^{\text {age }}$;

males with serum creatinine $\leq 0.9 \mathrm{mg} / \mathrm{dl}$ : $\mathrm{eGFR}=141 \times(\mathrm{se}-$ rum creatinine $/ 0.9)^{-0.411} \times(0.993)^{\text {age }}$;

males with serum creatinine $>0.9 \mathrm{mg} / \mathrm{dl}$ : eGFR $=141 \times$ (serum creatinine $/ 0.9)^{-1.209} \times(0.993)^{\text {age }}$;

(5) serum cystatin C was measured by nephelometry;

(6) GFR was estimated based on cystatin C calculation by: eGFR $=74.835 /(\text { serum cystatin } C)^{1.333}$;

(7) GFR was estimated based on cystatin $\mathrm{C}$ and creatinine by: $\mathrm{eGFR}=177.6 \times(\text { serum creatinine })^{-0.65} \times(\text { serum cystatin } \mathrm{C})^{-0.57}$ $\times$ age $^{-0.20} \times(0.82$ if female $)[14]$;

(8) plasma NGAL by immunoassay on the Triage platform (point of care system) [5]; levels below the limit of detection (60 $\mathrm{ng} / \mathrm{ml}$ ) were set to $30 \mathrm{ng} / \mathrm{ml}$. 
Statistical Analysis

Data are presented as means \pm SD. Values before and after treatment within the 2 groups were analyzed using the paired Student $t$ test. A p value below 0.05 was considered to be statistically significant. Correlations were calculated by the Spearman test. Statistical analyses were conducted with Graph Pad Prism (Graph Pad Software, San Diego, Calif., USA).

\section{Results}

\section{Hypothyroidism}

In the hypothyroid patients $(n=9)$, the mean free $T_{4}$ $\left(\mathrm{fT}_{4}\right)$ was $4.8 \pm 0.3 \mathrm{pmol} / \mathrm{l}$ (reference 11.7-28.0) at diagnosis and increased to $24.1 \pm 5.3 \mathrm{pmol} / 1$ when patients were treated with levothyroxine. When $\mathrm{fT}_{4}$ normalized, serum creatinine decreased significantly $(\mathrm{p}<0.001)$ from 1.2 to $0.9 \mathrm{mg} / \mathrm{dl}$ (reference $0.5-1.4$ ) and creatinine-based GFR estimations (reference $80-120 \mathrm{ml} / \mathrm{min}$ ) increased significantly (table 1a and fig. 1a): 24-hour creatinine clearance from $86 \pm 23$ to $115 \pm 36 \mathrm{ml} / \mathrm{min}(\mathrm{p}<0.001)$, calculated GFR by Cockroft-Gault from $92 \pm 14$ to 117 $\pm 16 \mathrm{ml} / \mathrm{min}(\mathrm{p}<0.001)$ and eGFR by the CKD-EPI equation from $68 \pm 12$ to $93 \pm 15 \mathrm{ml} / \mathrm{min}(\mathrm{p}<0.001)$. The combined (cystatin $\mathrm{C}$ and creatinine) formula for estimating GFR increased significantly from $81 \pm 10$ to 90 $\pm 11 \mathrm{ml} / \mathrm{min}(\mathrm{p}=0.01)$ as shown in table $1 \mathrm{a}$ and figure 2a. In contrast, serum cystatin $\mathrm{C}$ increased significantly $(\mathrm{p}=0.02)$ from $0.80 \pm 0.09$ to $0.88 \pm 0.09 \mathrm{mg} / \mathrm{l}$ and $\mathrm{eGFR}$ based on cystatin C decreased from $103 \pm 15$ to $90 \pm 11$ $\mathrm{ml} / \mathrm{min}(\mathrm{p}=0.02)$ as shown in table 1a and figure $3 \mathrm{a}$. There was no significant effect $(\mathrm{p}=0.9)$ on the low plasma NGAL levels $(39 \pm 27 \mathrm{ng} / \mathrm{ml}$ in hypothyroidism vs. $38 \pm$ $16 \mathrm{ng} / \mathrm{ml}$ in euthyroidism) as shown in figure 4.

\section{Hyperthyroidism}

In patients with hyperthyroidism $(\mathrm{n}=7)$, the mean $\mathrm{fT}_{4}$ was $27.1 \pm 8.34 \mathrm{pmol} / \mathrm{l}$ (reference 11.7-28.0) at diagnosis and decreased to $11.63 \pm 4.28 \mathrm{pmol} / 1$ following treatment with antithyroid drugs $(n=3)$ or radioiodine $(n=$ 4). When $\mathrm{fT}_{4}$ normalized, serum creatinine increased significantly ( $\mathrm{p}<0.001)$ from $0.63 \pm 0.10$ to $0.77 \pm 0.13 \mathrm{mg} /$ dl (reference 0.5-1.4), and creatinine-based GFR estimations (reference $80-120 \mathrm{ml} / \mathrm{min}$ ) decreased significantly (table $1 \mathrm{~b}$ and fig. 1b): 24-hour creatinine clearance from $132 \pm 26$ to $104 \pm 11 \mathrm{ml} / \mathrm{min}(\mathrm{p}=0.03)$, calculated GFR by Cockroft-Gault from $126 \pm 14$ to $103 \pm 8 \mathrm{ml} / \mathrm{min}$ $(\mathrm{p}=0.01)$ and eGFR by the CKD-EPI equation from 110 \pm 6 to $98 \pm 8 \mathrm{ml} / \mathrm{min}(\mathrm{p}=0.02)$. In contrast, serum cystatin $\mathrm{C}$ decreased significantly $(\mathrm{p}=0.01)$ from $1.07 \pm$ 0.21 to $0.82 \pm 0.08 \mathrm{mg} / \mathrm{l}$, and GFR based on cystatin C increased significantly $(\mathrm{p}<0.001)$ from $73 \pm 16$ to 100 $\pm 12 \mathrm{ml} / \mathrm{min}$ as shown in table $1 \mathrm{~b}$ and figure $3 \mathrm{~b}$. There was no significant change $(\mathrm{p}=0.76)$ for the combined (cystatin C and creatinine) GFR equation in patients with hyperthyroidism and after treatment, when reaching an euthyroid state as shown in table $1 \mathrm{~b}$ and figure $2 \mathrm{~b}$. There was no significant effect $(\mathrm{p}=0.61)$ on the low plasma NGAL levels (50 $\pm 25 \mathrm{ng} / \mathrm{ml}$ in hyperthyroidism versus $41 \pm 19 \mathrm{ng} / \mathrm{ml}$ in euthyroidism) as shown in figure 4 .

\section{Correlations between Thyroid Function and Kidney}

Function Tests

There is a positive, highly significant correlation $(\mathrm{r}=$ $0.76, \mathrm{p}<0.001$ ) between $\mathrm{fT}_{4}$ and cystatin $\mathrm{C}$ in patients with overt hypo- and hyperthyroidism as shown in figure 5.

\section{Discussion}

Thyroid and kidney function are known to interact, and thyroid dysfunction is known to cause significant changes in kidney function, especially to affect GFR $[1,15$, 16]. Different kidney function tests are used in everyday clinical practice: biomarkers like serum creatinine, serum cystatin C, plasma NGAL and estimations of the GFR by collected and calculated clearances (creatinine clearance measured in a 24-hour collection, calculated GFR by Cockroft-Gault or the CKD-EPI equation, estimated GFR based on cystatin C and estimated GFR based on both creatinine and cystatin $\mathrm{C}$ ). In case of chronic kidney disease (GFR $<60 \mathrm{ml} / \mathrm{min}$ ), the eGFR rate by the MDRD formulas is the best-validated approach [4]. The 'gold standard' tests for assessing kidney function are the more invasive tests like inulin clearance or isotopic studies.

Our study included several creatinine-based kidney function tests (serum creatinine, collected 24-hour creatinine clearance, calculated GFR by Cockroft-Gault, eGFR by the CKD-EPI equation); no previous study included collected 24-hour urine clearances and calculated GFRs. Our results on the 4 creatinine-based kidney function tests are in line with the previous reports [7]: in all 4 tests there was a significant decline of the eGFR in hypothyroidism and an increase in hyperthyroidism. The 24hour collected creatinine clearance was increased by 28 $\mathrm{ml} / \mathrm{min}$ to $132 \mathrm{ml} / \mathrm{min}$ in our hyperthyroid patients and decreased by $25 \mathrm{ml} / \mathrm{min}$ to $86 \mathrm{ml} / \mathrm{min}$ in our hypothyroid patients. These GFR values are very similar to the GFR by isotopic studies reported in the literature [17]. The Cockroft-Gault formula was published in 1976 [12], and nowadays it is still used very frequently for drug dosing, be- 


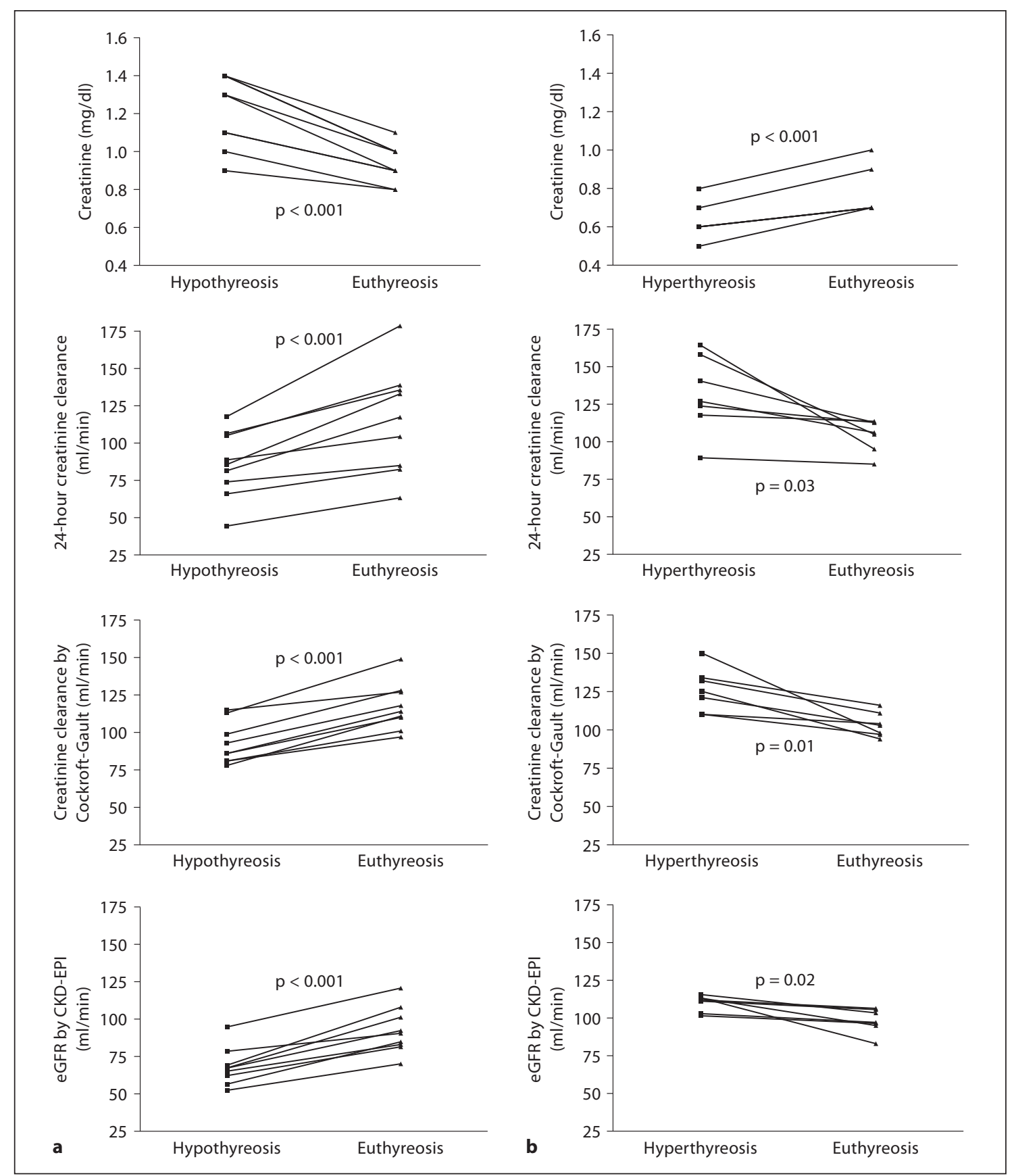

Fig. 1. Creatinine-based kidney function tests: 24 -hour creatinine clearance, calculated creatinine clearance by Cockroft-Gault, eGFR by CKD-EPI. a Hypothyreosis before (fT $4.8 \pm 0.3 \mathrm{pmol} / \mathrm{l})$ and after treatment $\left(\mathrm{fT}_{4} 24.1\right.$ $\pm 5.3 \mathrm{pmol} / \mathrm{l})$. b Hyperthyreosis before $\left(\mathrm{fT}_{4} 27.10 \pm 8.34 \mathrm{pmol} / \mathrm{l}\right)$ and after treatment $\left(\mathrm{fT}_{4} 11.63 \pm 4.28 \mathrm{pmol} / \mathrm{l}\right)$.

cause of its use in pharmacological studies and regulatory recommendations. Therefore, GFR calculation by Cockroft-Gault was included in the study protocol and provided very similar results to the 24 -hour collected creatinine clearance. The widespreadly used MDRD equa- tions are limited to chronic kidney disease (with GFR $<60$ $\mathrm{ml} / \mathrm{min}$ ), because of the well-known GFR underestimation in a population with normal GFR. Therefore, we chose the recently recommended CKD-EPI equation for our study population without known chronic kidney dis- 


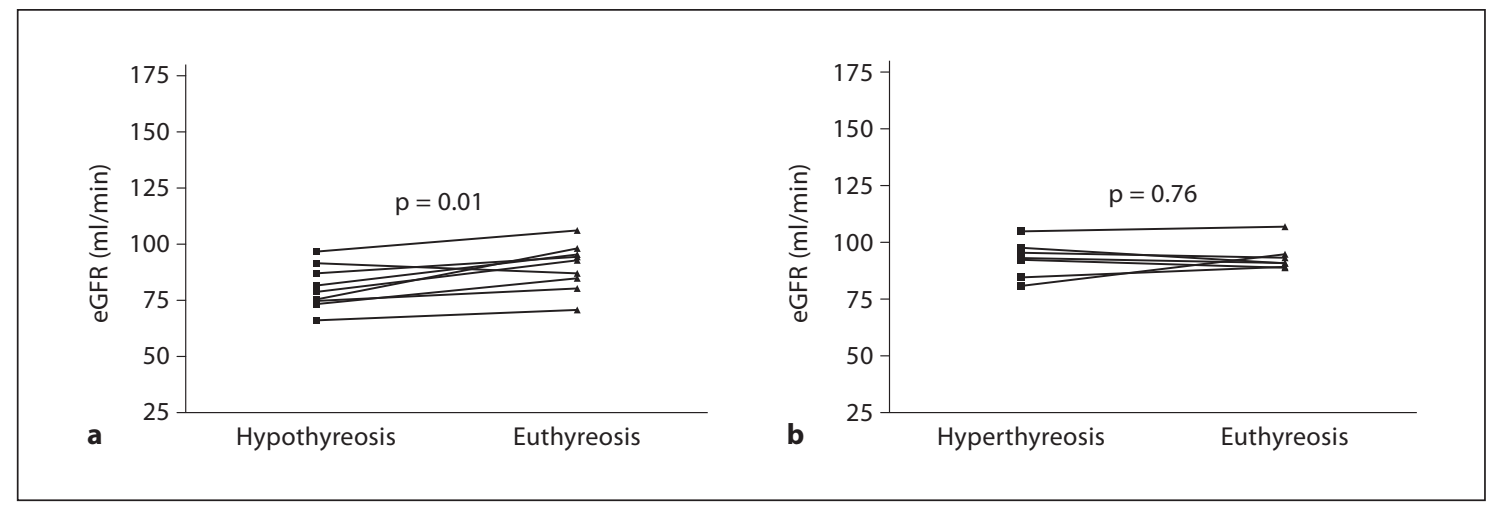

Fig. 2. eGFR based on a combined creatinine and cystatin $C$ formula. a Hypothyreosis before (fT $4.8 \pm 0.3$ $\mathrm{pmol} / \mathrm{l})$ and after treatment $\left(\mathrm{fT}_{4} 24.1 \pm 5.3 \mathrm{pmol} / \mathrm{l}\right)$. $\mathbf{b}$ Hyperthyreosis before $\left(\mathrm{fT}_{4} 27.10 \pm 8.34 \mathrm{pmol} / \mathrm{l}\right)$ and after treatment $\left(\mathrm{fT}_{4} 11.63 \pm 4.28 \mathrm{pmol} / \mathrm{l}\right)$.

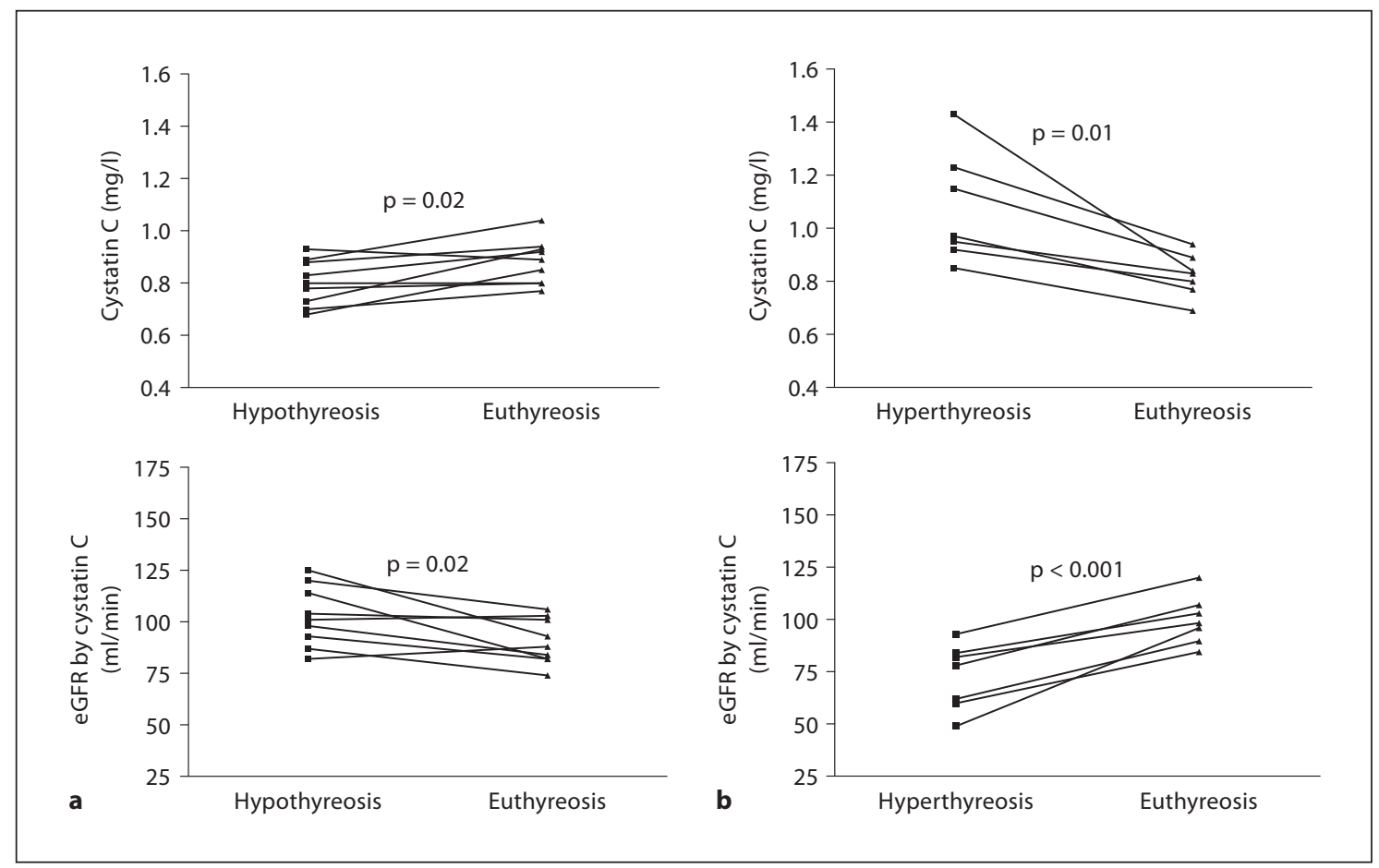

Fig. 3. Cystatin-C-based kidney function tests: serum cystatin $\mathrm{C}$ and eGFR. a Hypothyreosis before (fT $4.8 \pm$ $0.3 \mathrm{pmol} / \mathrm{l})$ and after treatment $\left(\mathrm{fT}_{4} 24.1 \pm 5.3 \mathrm{pmol} / \mathrm{l}\right)$. b Hyperthyreosis before $\left(\mathrm{fT}_{4} 27.10 \pm 8.34 \mathrm{pmol} / \mathrm{l}\right)$ and after treatment $\left(\mathrm{fT}_{4} 11.63 \pm 4.28 \mathrm{pmol} / \mathrm{l}\right)$.

ease [13]; nevertheless, the estimation of the GFR was lower than by 24 -hour collected creatinine clearance and Cockroft-Gault estimation. Studies on serum creatinine in thyroid disease indicate that GFR is rising in hyperthyroidism and falling in hypothyroidism [7]. This is in line with a significantly higher inulin clearance reported in patients with hyperthyroidism and a reduced GFR assessed by isotopic renal function studies reported in patients with hypothyroidism - both were reversible after normalizing $\mathrm{fT}_{4}[17-20]$. In patients with extreme thyroid 


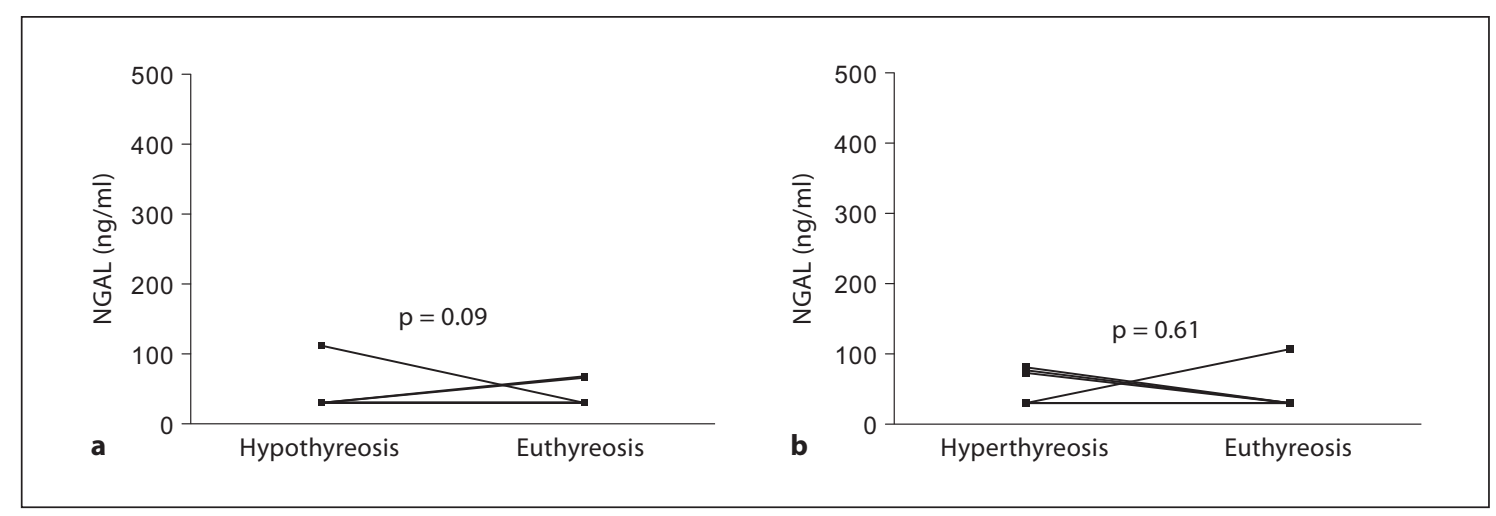

Fig. 4. Plasma NGAL. a Hypothyreosis before ( $\left.\mathrm{fT}_{4} 4.8 \pm 0.3 \mathrm{pmol} / \mathrm{l}\right)$ and after treatment $\left(\mathrm{fT}_{4} 24.1 \pm 5.3 \mathrm{pmol} / \mathrm{l}\right)$. b Hyperthyreosis before $\left(\mathrm{fT}_{4} 27.10 \pm 8.34 \mathrm{pmol} / \mathrm{l}\right)$ and after treatment $\left(\mathrm{fT}_{4} 11.63 \pm 4.28 \mathrm{pmol} / \mathrm{l}\right)$.

dysfunction, like those with myxedema, serum creatinine could probably underestimate the renal function, because creatinine depends on the metabolism of muscles $[21,22]$.

In the study protocol we included the well-established newer biomarker cystatin $\mathrm{C}$ for the measurements of kidney function [3]. Cystatin $\mathrm{C}$ may be superior to creatinine as a marker for GFR, and a more accurate marker in acute kidney injury. Cystatin $\mathrm{C}$ has advantages because concentrations in blood are not influenced by muscle mass, but several known factors, other than GFR, affect serum cystatin C levels [23-26], and there is an ongoing discussion about its widespread use. In our study, the cystatinC-based kidney function test showed complete inverse changes compared to the changes described above in creatinine-based kidney function tests: serum cystatin $\mathrm{C}$ levels and eGFR based on cystatin $C$ were significantly lower in hypothyroidism $(\mathrm{p}=0.02$ and $\mathrm{p}=0.02)$ and significantly higher in hyperthyroidism $(\mathrm{p}=0.01$ and $\mathrm{p}<$ 0.001 ). Furthermore, there is a highly significant positive correlation $(\mathrm{r}=0.76, \mathrm{p}<0.001)$ between $\mathrm{fT}_{4}$ and cystatin $\mathrm{C}$ in patients with overt hypo- and hyperthyroidism. These observations are in line with the findings from other groups $[8,9,27]$, indicating that cystatin $\mathrm{C}$ is a better marker of thyroid function than a kidney function test in this setting. It was speculated that the thyroid function is involved in the metabolism of cystatin C [28], as it has been described for $\beta_{2}$-microglobulin [29].

In the situation described above, with inverse behavior of creatinine and cystatin $\mathrm{C}$ in thyroid dysfunction, it is exciting to study a GFR equation based on both biomarkers, creatinine and cystatin C. We used the equation proposed by Stevens et al [14], and indeed there was no

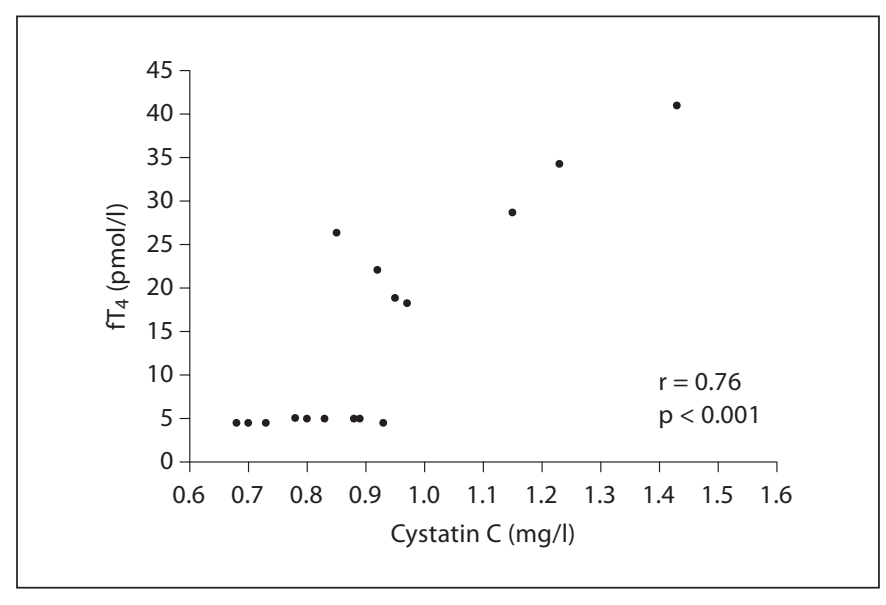

Fig. 5. Correlation between serum cystatin $\mathrm{C}$ and $\mathrm{fT}_{4}$.

significant change of estimated GFR before and after treatment of hyperthyroid patients. In hypothyroid patients there was a predominant 'creatinine effect' with a significant decrease in hypothyroidism compared to the euthyreotic state $(\mathrm{p}=0.01)$. Nevertheless, cystatin $\mathrm{C}$ seems to be worthless as a kidney function test in thyroid dysfunction; therefore, any cystatin-C-based equation should be avoided in this setting.

The impact on thyroid dysfunction on cystatin $\mathrm{C}$ is of special interest on the background of its recommended use as an earlier biomarker of acute kidney injury in emergency [30] and intensive care medicine $[6,31]$. In the emergency department [32] and especially in the intensive care unit, the prevalence of abnormal thyroid function tests is extremely high with more than $70 \%$ of the 
intensive care patients showing low total $\mathrm{T}_{3}$, and around $50 \%$ have low total $\mathrm{T}_{4}[33]$.

Several recent studies demonstrate that NGAL, measured in plasma or urine, is an earlier biomarker in acute injury [34-36]. Nevertheless, there are several known limitations, the clinically most important one is an increase in NGAL in inflammation [37]. NGAL is an NF$\kappa \mathrm{B}$-regulated gene and is furthermore known to be a survival factor for thyroid neoplastic cells [11]. In contrast to cystatin C, there was no significant change in NGAL levels before and after treatment of thyroid disorders.

In summary, thyroid function has a major influence on the vast majority of kidney function tests. Cystatin C is strongly influenced by the thyroid function and should be avoided in thyroid disorders, but there was no effect of the thyroid function on the low NGAL levels in patients without acute kidney injury. The recommended kidney function test in thyroid dysfunction is a creatinine-based GFR estimation (24-hour creatinine clearance, calculated GFR by Cockroft-Gault or the CKD-EPI equation). Furthermore, kidney and thyroid function should always be used together to avoid misleading interpretations.

\section{Acknowledgment}

This study was supported by the Robert Bosch Foundation Stuttgart, Germany.

\section{Disclosure Statement}

No conflict of interest declared.

\section{References}

1 Iglesias P, Diez JJ: Thyroid dysfunction and kidney disease. Eur J Endocrinol 2009;160: 503-515.

-2 Vargas F, Moreno JM, Rodriguez-Gomez I, Wangensteen R, Osuna A, Alvarez-Guerra $M$, Garcia-Estan J: Vascular and renal function in experimental thyroid disorders. Eur J Endocrinol 2006;154:197-212.

3 Herget-Rosenthal S, Bokenkamp A, Hofmann W: How to estimate GFR-serum creatinine, serum cystatin $\mathrm{C}$ or equations? Clin Biochem 2007;40:153-161.

4 Levey AS, Bosch JP, Lewis JB, Greene T, Rogers N, Roth D: A more accurate method to estimate glomerular filtration rate from serum creatinine: a new prediction equation. Modification of diet in renal disease study group. Ann Intern Med 1999;130:461-470.

$\checkmark 5$ Dent CL, Ma Q, Dastrala S, Bennett M, Mitsnefes MM, Barasch J, Devarajan P: Plasma neutrophil gelatinase-associated lipocalin predicts acute kidney injury, morbidity and mortality after pediatric cardiac surgery: a prospective uncontrolled cohort study. Crit Care 2007;11:R127.

-6 Herget-Rosenthal S, Marggraf G, Husing J, Goring F, Pietruck F, Janssen O, Philipp T, Kribben A: Early detection of acute renal failure by serum cystatin C. Kidney Int 2004; 66:1115-1122.

7 Kreisman SH, Hennessey JV: Consistent reversible elevations of serum creatinine levels in severe hypothyroidism. Arch Intern Med 1999;159:79-82.

-8 Fricker M, Wiesli P, Brandle M, Schwegler B, Schmid C: Impact of thyroid dysfunction on serum cystatin C. Kidney Int 2003;63:19441947.
9 Goede DL, Wiesli P, Brandle M, Bestmann L, Bernays RL, Zwimpfer C, Schmid C: Effects of thyroxine replacement on serum creatinine and cystatin $\mathrm{C}$ in patients with primary and central hypothyroidism. Swiss Med Wkly 2009;139:339-344.

10 Wiesli P, Schwegler B, Spinas GA, Schmid C: Serum cystatin $C$ is sensitive to small changes in thyroid function. Clin Chim Acta 2003; 338:87-90

-11 Iannetti A, Pacifico F, Acquaviva R, Lavorgna A, Crescenzi E, Vascotto C, Tell G, Salzano AM, Scaloni A, Vuttariello E, Chiappetta G, Formisano S, Leonardi A: The neutrophil gelatinase-associated lipocalin (NGAL), an NF-kappaB-regulated gene, is a survival factor for thyroid neoplastic cells. Proc Natl Acad Sci USA 2008; 105:1405814063.

12 Cockcroft DW, Gault MH: Prediction of creatinine clearance from serum creatinine. Nephron 1976;16:31-41.

13 Levey AS, Stevens LA, Schmid CH, Zhang YL, Castro AF 3rd, Feldman HI, Kusek JW, Eggers P, Van Lente F, Greene T, Coresh J: A new equation to estimate glomerular filtration rate. Ann Intern Med 2009;150:604612.

14 Stevens LA, Coresh J, Schmid CH, Feldman HI, Froissart M, Kusek J, Rossert J, Van Lente F, Bruce RD 3rd, Zhang YL, Greene T, Levey AS: Estimating GFR using serum cystatin C alone and in combination with serum creatinine: a pooled analysis of 3,418 individuals with CKD. Am J Kidney Dis 2008;51: 395-406.
15 Bradley SE, Stephan F, Coelho JB, Reville P: The thyroid and the kidney. Kidney Int 1974; 6:346-365.

16 Ford RV, Owens JC, Curd GW Jr, Moyer JH, Spurr CL: Kidney function in various thyroid states. J Clin Endocrinol Metab 1961;21: 548-553.

17 Villabona C, Sahun M, Roca M, Mora J, Gomez N, Gomez JM, Puchal R, Soler J: Blood volumes and renal function in overt and subclinical primary hypothyroidism. Am J Med Sci 1999;318:277-280.

18 Karanikas G, John P, Wahl K, Schuetz M, Dudczak R, Willheim M: T-lymphocyte cytokine production patterns in nonimmune severe hypothyroid state and after thyroid hormone replacement therapy. Thyroid 2004; 14:488-492.

19 Hlad CJ Jr, Bricker NS: Renal function and ${ }^{131}$ I clearance in hyperthyroidism and myxedema. J Clin Endocrinol Metab 1954;14: 1539-1550.

20 Ford HC, Lim WC, Chisnall WN, Pearce JM: Renal function and electrolyte levels in hyperthyroidism: urinary protein excretion and the plasma concentrations of urea, creatinine, uric acid, hydrogen ion and electrolytes. Clin Endocrinol (Oxf) 1989;30:293301.

21 Khaleeli AA, Edwards RH: Effect of treatment on skeletal muscle dysfunction in hypothyroidism. Clin Sci (Lond) 1984;66:6368.

22 Kurahashi M, Kuroshima A: Mechanism of thyroid-induced creatinuria in rat, with special reference to creatine synthesis in liver and creatine loss from skeletal muscle. Jpn J Physiol 1976;26:279-288. 
-23 Filler G, Bokenkamp A, Hofmann W, Le Bricon T, Martinez-Bru C, Grubb A: Cystatin C as a marker of GFR - history, indications, and future research. Clin Biochem 2005;38: $1-8$.

24 Fliser D, Ritz E: Serum cystatin c concentration as a marker of renal dysfunction in the elderly. Am J Kidney Dis 2001;37:79-83.

25 Dharnidharka VR, Kwon C, Stevens G: Serum cystatin $\mathrm{C}$ is superior to serum creatinine as a marker of kidney function: a metaanalysis. Am J Kidney Dis 2002;40:221-226.

-26 Ognibene A, Mannucci E, Caldini A, Terreni A, Brogi M, Bardini G, Sposato I, Mosconi V, Salvadori B, Rotella CM, Messeri G: Cystatin $\mathrm{C}$ reference values and aging. Clin Biochem 2006;39:658-661.

-27 Manetti L, Pardini E, Genovesi M, Campomori A, Grasso L, Morselli LL, Lupi I, Pellegrini G, Bartalena L, Bogazzi F, Martino E: Thyroid function differently affects serum cystatin $\mathrm{C}$ and creatinine concentrations. J Endocrinol Invest 2005;28:346-349.
28 Jayagopal V, Keevil BG, Atkin SL, Jennings PE, Kilpatrick ES: Paradoxical changes in cystatin $\mathrm{C}$ and serum creatinine in patients with hypo- and hyperthyroidism. Clin Chem 2003;49:680-681.

29 Roiter I, Da Rin G, De Menis E, Foscolo GC, Legovini P, Conte N: Increased serum beta2microglobulin concentrations in hyperthyroid states. J Clin Pathol 1991;44:73-74.

30 Soto K, Coelho S, Rodrigues B, Martins H, Frade F, Lopes S, Cunha L, Papoila AL, Devarajan $\mathrm{P}$ : Cystatin $\mathrm{C}$ as a marker of acute kidney injury in the emergency department. Clin J Am Soc Nephrol 2010;5:1745-1754.

-31 Delanaye P, Lambermont B, Chapelle JP, Gielen J, Gerard P, Rorive G: Plasmatic cystatin $\mathrm{C}$ for the estimation of glomerular filtration rate in intensive care units. Intensive Care Med 2004;30:980-983.

32 Pimentel L, Hansen KN: Thyroid disease in the emergency department: a clinical and laboratory review. J Emerg Med 2005;28: 201-209.

\$3 Ray DC, Macduff A, Drummond GB, Wilkinson E, Adams B, Beckett GJ: Endocrine measurements in survivors and nonsurvivors from critical illness. Intensive Care Med 2002;28:1301-1308.
>34 Mishra J, Ma Q, Prada A, Mitsnefes M, Zahedi K, Yang J, Barasch J, Devarajan P: Identification of neutrophil gelatinase-associated lipocalin as a novel early urinary biomarker for ischemic renal injury. J Am Soc Nephrol 2003; 14:2534-2543.

35 Bolignano D, Donato V, Coppolino G, Campo S, Buemi A, Lacquaniti A, Buemi M: Neutrophil gelatinase-associated lipocalin (NGAL) as a marker of kidney damage. Am J Kidney Dis 2008;52:595-605.

36 Mishra J, Dent C, Tarabishi R, Mitsnefes MM, Ma Q, Kelly C, RuffSM, Zahedi K, Shao M, Bean J, Mori K, Barasch J, Devarajan P: Neutrophil gelatinase-associated lipocalin (NGAL) as a biomarker for acute renal injury after cardiac surgery. Lancet 2005;365:12311238.

-37 Xu S, Venge P: Lipocalins as biochemical markers of disease. Biochim Biophys Acta 2000;1482:298-307. 